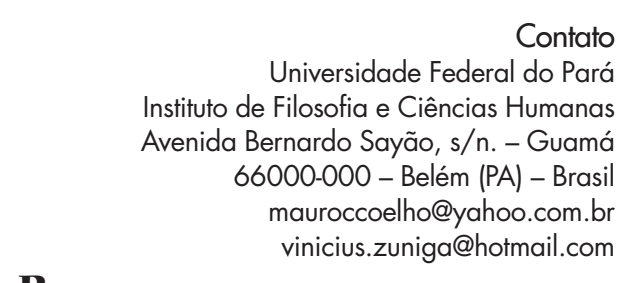

Contato Instituto de Filosofia e Ciências Humanas Bernardo Sayão, s/n. - Guamá 6000-000 - Belém (PA) - Brasil vinicius.zuniga@hotmail.com

\section{NEM HERÓIS, NEM VILÕES: \\ O LUGAR DOS \\ DIRETORES DE POVOAÇÕES NAS DINÂMICAS DE TRANSGRESSÃO À LEI DO DIRETÓRIO DOS ÍNDIOS (1757-1798)}

\author{
Mauro Cezar Coelho* \\ Universidade Federal do Pará \\ Belém - Pará - Brasil
}

Vinícius Zúniga Melo**

Universidade Federal do Pará

Belém - Pará - Brasil

\title{
Resumo
}

Este trabalho tem por objetivo melhor compreender a atuação dos diretores de povoações - agentes responsáveis pela tutela dos indígenas aldeados durante a vigência do Diretório dos Índios. Destacaremos duas questões. Primeira: o universo socioeconômico dos diretores em seus locais de trabalho, as povoações de índios. Segunda: o caráter histórico, e não moral, das transgressões cometidas por esses sujeitos. Tal objetivo se deve ao fato de considerarmos limitada a única visão formulada pela historiografia em relação aos diretores: agentes que, em razão de suas ações, foram decisivos para o fracasso do Diretório.

\section{Palavras-chave}

Diretório dos Índios - diretores de povoação - transgressões à lei.

* Doutor pelo Programa de Pós-Graduação em História Social da Faculdade de Filosofia, Letras e Ciências Humanas da Universidade de São Paulo. Professor adjunto na Faculdade de História do Instituto de Filosofia e Ciências Humanas. Agências de fomento: Conselho Nacional de Desenvolvimento Científico e Tecnológico e Universidade Federal do Pará.

** Mestrando do Programa de Pós-Graduação em História Social da Amazônia, do Instituto de Filosofia e Ciências Humanas. Agências de fomento: Conselho Nacional de Desenvolvimento Científico e Tecnológico e Universidade Federal do Pará. 


\title{
NEITHER HEROES, \\ NOR VILLAINS:
}

THE PLACE OF VILLAGE'S

ADMINISTRATORS IN

DYNAMIC OF THE

TRANSGRESSION

TO LAW INDIANS'

DIRECTORY

(1757-1798)

Contact

Universidade Federal do Pará Instituto de Filosofia e Ciências Humanas Avenida Bernardo Sayão, s/n. - Guamá 66000-000 - Belém (PA) - Brasil mauroccoelho@yahoo.com.br vinicius.zuniga@hotmail.com

\section{Mauro Cezar Coelho}

Universidade Federal do Pará

Belém - Pará - Brasil

\section{Vinícius Zúniga Melo}

Universidade Federal do Pará

Belém - Pará - Brasil

\begin{abstract}
This paper aims to understanding better the actions of villages' administrators - agents responsible for settled Indians' tutelage during the term of the Indians' Directory. We will highlight two issues. First, the socioeconomic universe of administrators in their workplaces, the indians' villages. Second, the historical character, and not moral, of transgressions committed by these subjects. This goal is because we consider limited the only vision formulated by historiography in relation to administrators: agents, because of their actions, that were decisive for the failure of the directory.
\end{abstract}

\section{Keywords}

Indians' Directory - village's administrators - transgressions to law. 


\section{Introdução}

O presente trabalho dialoga com parte da historiografia ocupada com a análise do Diretório dos Índios (1757-1798). Promulgado em 1757, o Diretório conformava um conjunto de dispositivos que buscava regular a Lei de Liberdades de 1755, responsável por erradicar quaisquer formas de submissão dos indígenas à escravidão e equipará-los aos demais vassalos da Coroa lusa. ${ }^{1}$ A lei de 1755 e o Diretório se constituíam em duas legislações indigenistas portuguesas, as quais visavam atender um conjunto de interesses da metrópole: povoar e garantir o Vale Amazônico como território português, desenvolver economicamente a região e fortalecer nela o poder real. Ambas pautavam-se pela integração dos povos indígenas à sociedade colonial, por meio de uma série de iniciativas relacionadas: a promoção de descimentos, ${ }^{2}$ o incentivo a casamentos mistos, a distribuição de honrarias e de responsabilidades às chefias indígenas, além de outras iniciativas.

Nesse período, vigorava o Tratado de Madri, assinado em 1750 pelas coroas ibéricas, que estabelecia um alargamento dos domínios lusos ao norte da América portuguesa. Se ao menos legalmente amplas áreas do Vale Amazônico eram de Portugal, na prática, era imperioso proteger, povoar e desenvolver economicamente essa região.

No entanto, ainda que relacionado a esses interesses do reino, o Diretório surgiu em função das relações mantidas no Vale Amazônico, de modo que esteve, desde o início, vinculado às demandas da colônia, especialmente ao clamor pela força de trabalho indígena, mão de obra preferencial da região. As circunstâncias da colônia definiram grande parte das diretrizes con-

\footnotetext{
1 Francisco Xavier de Mendonça Furtado. Lei régia. 3 maio 1757. DIRECTORIO que se deve observar nas Povoaçoens dos Índios do Pará, e Maranhão em quanto Sua Magestade não mandar o contrário. In: ALMEIDA, Rita Heloísa de. O Diretório dos Índios: um projeto de civilização no Brasil do século XVIII. Brasília: UnB, 1997; Lei régia. 6 maio 1755. LEI porque V. Magestade ha por bem restituir aos Índios do Grão-Pará e Maranhão a liberdade de suas pessoas, bens e commercio. In: MOREIRA NETO, Carlos de Araújo. Índios na Amazônia, de maioria à minoria (1750-1850). Petrópolis: Vozes, 1988, p. 152-164.

2 Os descimentos se constituíam no processo pelo qual os indígenas eram arregimentados de seus locais de origem para as povoações portuguesas. Sobre como se dava tal arregimentação, quem a realizava e qual a sua importância, ver: DOMINGUES, Ângela. Quando os índios eram vassalos. Colonização e relações de poder no Norte do Brasil na segunda metade do século XVIII. Lisboa: Comissão Nacional para as Comemorações dos Descobrimentos Portugueses, 2000, p. 136-151; COELHO, Mauro Cezar. Do sertão para o mar. Um estudo sobre a experiência portuguesa na América, a partir da colônia: o caso do Diretório dos Índios (1751-1798). Tese de doutorado, História, Programa de Pós-Graduação em História Social, Universidade de São Paulo, 2005, p. 203-207.
} 
tidas nessa lei, em especial a garantia de acesso aos trabalhadores índios. Por isso, o Diretório buscava equacionar, de um lado, as projeções da metrópole e, de outro, as expectativas da colônia. ${ }^{3}$

A historiografia a que nos referiremos conformou-se desde fins do dezenove por obras voltadas para a compreensão de processos mais amplos, cristalizando o argumento de que o Diretório soçobrou muito em função da ação perniciosa dos diretores das povoações de índios.

Este artigo oferece outra dimensão da figura dos diretores. Temos por objetivo melhor compreender a atuação desses sujeitos, destacando duas questões. A primeira delas diz respeito ao universo socioeconômico dos diretores dentro das povoações de índios. ${ }^{4}$ Para tanto, atentaremos para alguns pontos relacionados ao seu dia a dia nesses espaços, como o grau de acesso que tinham a importantes fontes de riqueza locais: os produtos extrativos, os gêneros agrícolas e a mão de obra indígena.

A segunda questão está relacionada ao encaminhamento dado à figura dos diretores. Não nos ocupamos com a questão do sucesso ou do fracasso do Diretório dos Índios, e a parcela de responsabilidade dos diretores no desfecho dessa lei. Esses sujeitos surgem neste estudo como agentes fincados no contexto de sua época e, portanto, não são vistos como "mocinhos" ou "vilões" - a despeito dos juízos que lhes eram destinados por seus contemporâneos. Partindo dessa perspectiva, esse trabalho não fornece sentido moral às transgressões dos diretores, mas sim histórico, em que infringir o Diretório era a regra no Vale Amazônico da segunda metade do século XVIII, pois era entendida como prática indispensável para a sobrevivência na região.

\section{As diretorias e a produção historiográfica}

No primeiro dos 95 parágrafos do Diretório dos Índios constava que em cada povoação haveria um diretor, nomeado pelo governador do Estado, "dotado de bons costumes, zelo, prudência, verdade, ciência da língua e de todos os mais requisitos necessários". ${ }^{5}$ Esses diretores seriam os responsáveis pela tutela do indígena no interior das vilas e lugares erigidos pelo Diretó-

\footnotetext{
COELHO, Mauro Cezar, op. cit., 2005.

4 As povoações de índios compreendiam os antigos aldeamentos missionários alçados à condição de vilas e lugares pelo Diretório dos Índios. Era nesses espaços que os diretores desempenhavam a sua função.

5 Francisco Xavier de Mendonça Furtado. Lei régia. 3 maio 1757. DIRECTORIO que se deve observar... §1. In: ALMEIDA, Rita Heloísa de, op. cit., 1997.
} 
rio dos Índios. Com a escravização proibida desde a promulgação da Lei de Liberdade de 1755, o indígena trabalharia a serviço dos moradores ou do Estado mediante pagamento: os primeiros empregavam os índios em diversas atividades - agricultura, coleta de gêneros, serviços domésticos; o Estado utilizava os indígenas nas obras públicas, nas expedições oficiais, na defesa do território, entre outros serviços. Os moradores interessados na mão de obra indígena deveriam apresentar "portarias" emitidas pelo governador do Estado às chefias indígenas da povoação, os principais, que eram encarregados de realizar a distribuição dos trabalhadores aos moradores, conforme a quantidade prevista pelas ditas "portarias". Todo esse processo, no entanto, deveria ocorrer sob a supervisão do diretor, que era também o responsável por administrar a remuneração devida aos indígenas, e receber dos moradores o pagamento pelo trabalho realizado por seus tutelados. ${ }^{6}$ Essas não eram, porém, as únicas atribuições dos diretores nas vilas e lugares de índios.

Concebido também como uma lei "civilizatória" em relação aos povos indígenas, o Diretório estabelecia que os diretores estimulassem o uso da língua portuguesa entre os índios e prezassem para que estes fossem honrados e estimados de acordo com seus cargos. Eram aconselhados a animar os indígenas para o desenvolvimento do comércio e do trabalho agrícola em suas próprias terras. Deveriam, ainda, incentivar uma relação amistosa entre indígenas e brancos no interior das povoações, assim como o casamento entre eles. ${ }^{7}$

O diretor tinha como função também participar ativamente do processo de cálculo e arrecadação dos dízimos. Eram encarregados de auxiliarem na distribuição e no controle da mão de obra indígena e na administração da povoação, cuidando, entre outras coisas, da construção de casas, câmaras e cadeias públicas. Em troca, os diretores deveriam receber a sexta parte de todos os gêneros não comestíveis extraídos e cultivados pelos índios. ${ }^{8}$

A lei do Diretório acabou por eleger, então, os diretores em um dos eixos de sua execução. Indício relevante da importância assumida por eles é o volume de considerações que analisam seu desempenho e os responsabilizam pelos destinos da lei formulada. Isto é, alguns críticos, ainda durante a segunda metade do século XVIII, apontavam o insucesso de muitos dos

\footnotetext{
${ }^{6}$ Francisco Xavier de Mendonça Furtado. Lei régia. 3 maio 1757. DIRECTORIO que se deve observar... §§ 61-62; 68-69. In: idem.

7 Francisco Xavier de Mendonça Furtado. Lei régia. 3 maio 1757. DIRECTORIO que se deve observar... §§ 6; 9; 22-23; 36; 87 e 88. In: idem.

${ }^{8}$ Francisco Xavier de Mendonça Furtado. Lei régia. 3 maio 1757. DIRECTORIO que se deve observar... $\S \S 27-33$; 60-63, 65-69 e 71-73; 74; 34. In: idem.
} 
dispositivos do Diretório, atribuindo aos desvios cometidos pelos diretores uma das razões para esse desfecho. Um dos principais agentes a partilhar dessa visão foi Francisco de Sousa Coutinho, último governador do Estado do Grão-Pará e Rio Negro ao tempo do Diretório, e responsável pelo fim desse dispositivo legal. Muitas de suas críticas ao comportamento dos diretores encontram-se sintetizadas em um ofício enviado ao secretário de Estado da Marinha e Ultramar, d. Rodrigo de Sousa Coutinho, no qual consta, em anexo, a "Informação Sobre a Civilização dos Índios do Pará". Dentre outros fatores que levaram a um resultado não satisfatório acerca da civilização dos indígenas, está o desempenho dos diretores de povoações. Na visão do govenador, esses sujeitos eram tomados pelos "excessos e abusos", e diz ainda que a tutela exercida por eles não deveria ter se prolongado por tanto tempo. Para Sousa Coutinho, "em quanto se não remover este obstáculo dos Directores não se pode pretender Civilização, nem conservação".?

Ao analisarmos a bibliografia sobre o tema, constatamos que parte dela toma por base tais críticas para construir suas conclusões. Isto é, ao se debruçarem sobre a documentação, essa historiografia acaba assumindo como verdadeiros os juízos formulados por Souza Coutinho, entre outros, elegendo, assim, os diretores como um dos principais responsáveis pelo fracasso do Diretório, devido ao seu comportamento na realização da função. ${ }^{10}$

De modo geral, segundo essa formulação, os diretores, em vez de prezarem pelos interesses dos indígenas, de civilizá-los e de exercerem uma tutela branda e suave, conforme demandava a legislação, os tratavam com violência, dispunham de seu trabalho para si e/ou os cediam de forma ilegal para os moradores. Ações como essas teriam prejudicado o bom andamento

\footnotetext{
9 Francisco de Sousa Coutinho. Por volta de 3/8/1797. Documento anexado ao ofício de Francisco de Sousa Coutinho, ao secretário de Estado da Marinha e Ultramar, d. Rodrigo de Sousa Coutinho, em 3 ago.1797. AHU, cx. 109, n. 8610.

${ }^{10}$ Ver: AZEVEDO, João Lúcio de. Os jesuítas no Grão-Pará: suas missões e a colonização - bosquejo histórico com vários documentos inéditos. Belém: Secretaria de Estado e Cultura, 1999, p. 281-188; 309-316; PRADO JÚNIOR, Caio. Formação do Brasil contemporâneo: colônia. $1^{\mathrm{a}}$ ed. São Paulo: Companhia das Letras, 2011, p. 97-102; ALMEIDA, Maria Regina Celestino de. Os vassalos d'el rey nos confins da Amazônia: a colonização da Amazônia ocidental. 1750-1798. Dissertação de mestrado, História, Instituto de Ciências Humanas e Filosofia, Universidade Federal Fluminense, 1990, p. 134; ALMEIDA, Rita Heloísa de, op. cit., 1997, p. 168-169; 241; 321-349; HEMMING, John. Árvore de rios: a história da Amazônia. São Paulo: Senac-SP, 2011, p. 127-137. Essa historiografia atribui também a outros fatores o fracasso do Diretório dos Î́ndios: constante retirada de indígenas das povoações para o trabalho nos serviços reais; epidemias; fugas indígenas das vilas e lugares; não adaptação dos índios à produção de excedentes agrícolas e, finalmente, a vocação extrativa da região.
} 
do Diretório e impedido a concretização de alguns dos objetivos propostos por essa lei. Por utilizarem da mão de obra indígena em benefício próprio e, em certos casos, facilitarem o acesso de moradores a ela, muitos indígenas não ficavam o tempo devido nas povoações para o desenvolvimento de suas roças particulares, para a realização do comércio e para assimilar os valores europeus. Mesmo em trabalhos que não discutem a questão do êxito do Diretório, a indicação de desvios dos objetivos originais está presente: um deles argumenta que essa lei proporcionou aos indígenas uma experiência trágica, pois, em função da busca por vantagens pessoais, os diretores deixaram os índios aldeados "a mercê dos colonos".11 Outro estudo afirma que os diretores, em muitas ocasiões, não colocavam os interesses da metrópole em primeiro lugar, e que a sua corrupção "era um fato evidente", muito em função do trato com os indígenas. ${ }^{12}$

Longe de desconsiderar as contribuições significativas fornecidas por essas obras à historiografia referente à história da Amazônia e do Brasil, e que das quais fazemos usos nesse estudo, buscamos, aqui, compreender melhor o trabalho realizado pelos diretores, pois consideramos problemática uma única visão formulada sobre eles, a qual é baseada em análises feitas por outros indivíduos acerca de seu desempenho. Além do mais, essa visão está assentada em um olhar metropolitano. Em outras palavras, as análises a que nos referimos buscam verificar se os diretores cumpriam as diretrizes colocadas pela Coroa portuguesa. Constatado o descumprimento, as análises os assumem como sujeitos que mais pensavam nos próprios interesses do que nos de Portugal, contribuindo para a não realização de uma série de objetivos do Diretório e, consequentemente, para o seu fracasso.

Os documentos cotejados pela pesquisa são provenientes de dois arquivos: o Arquivo Público do Pará (APEP) e o Arquivo Histórico Ultramarino (AHU). Recorremos aos seguintes tipos de fontes: ofícios, requerimentos, certidões, devassas e mapas de rendimentos das vilas e lugares de índios. Utilizamo-nos também de três fontes impressas: a Lei de liberdade do índio de 1755, a própria Lei do Diretório dos Índios e as crônicas do padre João

\footnotetext{
${ }^{11}$ SOUZA JÚNIOR, José Alves de. Tramas do cotidiano: religião, política, guerra enegócios no Grão-Pará do setecentos. Um estudo sobre a Companhia de Jesus e a política pombalina. Tese de doutorado, História, Programa de Pós-Graduação em História Social, Pontifícia Universidade Católica de São Paulo, 2009, p. 19; 157.

${ }^{12}$ FONTENELE, Francisca Nescylene. Grão-Pará pombalina: trabalho, desigualdade e relações de Poder. Dissertação de mestrado, História, Programa de Estudos Pós-Graduados, Pontifícia Universidade Católica de São Paulo, 2008, p. 140.
} 
Daniel. ${ }^{13}$ Oportunamente, situaremos a importância de cada uma delas para o trabalho. O resultado a que chegamos dá conta de duas questões.

Primeiro, destacaremos o universo socioeconômico dos diretores dentro das povoações de índios. Nelas, enquanto notaremos a proximidade de muitos desses agentes com o extrativismo, com a agricultura e com os povos indígenas, observaremos também que vários deles conviviam com diferentes tipos de empecilhos, inclusive com a escassez dessas fontes de riqueza. Segundo, este estudo aborda os diretores como sujeitos imersos no Vale Amazônico ao tempo da segunda metade do século XVIII. Isto é, analisamos as suas transgressões ${ }^{14}$ não por uma perspectiva moral, mas sim histórica, em que a infração ao Diretório era recorrente entre os muitos indivíduos que faziam parte dessa sociedade, pois se constituía em uma prática fundamental para a sobrevivência na região.

\section{O universo socioeconômico dos diretores no interior das povoações}

Ocupar uma diretoria ao tempo do Diretório dos Índios, de fato, poderia significar estar em constante contato com importantes fontes de riqueza do Vale Amazônico: os gêneros do sertão, ${ }^{15}$ os produtos agrícolas e a mão de obra indígena. No que tange às primeiras, a legislação estabelecia que todas as povoações enviassem expedições de coleta aos sertões, de modo que os diretores eram responsáveis pela sua organização e pelo controle do que era extraído. Em relação à agricultura, o Diretório demandava a existência de lavouras em cada uma das povoações com vista à produção de mandioca, feijão, milho, arroz e outros gêneros comestíveis, além do algodão e do tabaco. O cultivo da mandioca voltar-se-ia para o abastecimento do arraial do

\footnotetext{
${ }^{15}$ Nas referências às documentações serão utilizadas siglas, as quais correspondem aos seguintes termos: cx. - caixa, núm. - número, cód. - códice.

${ }^{14}$ Utilizamos o termo "transgressão", pois os próprios habitantes do Vale Amazônico ao tempo da segunda metade do século XVIII faziam uso dele para se referir a ações contrárias à lei do Diretório dos Índios. Ver: Bispo do Pará, d. Frei Miguel de Bulhões e Sousa. Cópia de pastoral. 20 mar. 1759. Cópia anexada ao ofício de d. Frei Miguel de Bulhões e Sousa, para o secretário de Estado da Marinha e Ultramar, Tomé Joaquim da Costa Corte Real, de 15 jul. 1758. AHU, cx. 43, núm. 3956; Governador do estado do Grão-Pará e Maranhão, Manuel Bernardo de Mello e Castro. Ofício. 12 out. 1761. Ofício ao secretário de estado da Marinha e Ultramar, Francisco Xavier de Mendonça Furtado. AHU, cx. 50, núm. 4621.

15 Os gêneros do sertão eram uma série de produtos extraídos da floresta, como a canela, pimenta, salsaparrilha, castanha, breu, cravo, anil, andiroba e copaíba, entre outros.
} 
Rio Negro, para o socorro dos moradores de Belém e para o provimento das tropas que guarneciam o Estado. As lavouras das povoações eram denominadas de "roças do comum", e deveriam contar com o incentivo e supervisão dos diretores. ${ }^{16}$ Já em relação à mão de obra indígena, qualquer ação relacionada aos índios aldeados envolvia o diretor, afinal, ele exercia o papel de tutor. As próprias obrigações dos diretores, aqui referidas, demonstram essa questão. Portanto, para muitos sujeitos, o exercício de uma diretoria poderia render bons frutos. Vejamos informações que apontam para a importância do extrativismo, da agricultura e da força de trabalho indígena na região.

No Vale Amazônico, ao tempo do Diretório, predominou a atividade extrativa, junto do cultivo de produtos como arroz, cacau, cana-de-açúcar e mandioca. Destaque para o cacau e o amplo mercado externo que esse gênero possuía. Entre 1756 e 1777, o cacau representou 61\% do valor total das exportações da Amazônia, fosse ele extraído ou cultivado. O cacau coletado, porém, foi o que predominou desde que o produto passou a ser exportado em larga escala pela região, a partir de 1730, de modo que ao longo do século XVIII e início do XIX, a economia amazônica dependeu do cacau silvestre. ${ }^{17}$ Segundo Francisco de Assis Costa, entre os anos de 1755 a 1777, o extrativismo predominou na capitania do Pará. Entre 1777 a 1798, porém, houve um importante crescimento da exportação dos produtos agropecuários. ${ }^{18}$ Parte da historiografia, portanto, aponta o extrativismo como a principal atividade econômica durante o Diretório. ${ }^{19}$

Os gêneros do sertão e da agricultura também eram consumidos em larga escala internamente, o que demonstra a sua importância em nível lo-

\footnotetext{
${ }^{16}$ Francisco Xavier de Mendonça Furtado. Lei régia. 3 maio 1757. DIRECTORIO que se deve observar... \$§ 46-58; 20-26. In: ALMEIDA, Rita Heloísa de, op. cit., 1997.

${ }^{17}$ COELHO, Mauro Cezar, op. cit., 2005, p. 236; DIAS, Manuel Nunes. As frotas do cacau da Amazônia (1756-1777): Subsídios para o estudo do fomento ultramarino português no século XVIII. Revista de História. São Paulo: fasc. 50, 1962, p. 39-40; ALDEN, Dauril. O significado da produção de cacau na região amazônica no fim do período colonial: um ensaio de História econômica comparada. Belém: UFPA/NAEA, 1974, p. 25-27.

${ }^{18}$ COSTA, Francisco de Assis. Lugar e significado da gestão pombalina na economia colonial do Grão-Pará. Nova Economia. Belo Horizonte: v. 20, fasc. 1, 2010, p. 187-193; 197-198.

${ }^{19}$ FERREIRA REIS, Arthur Cezar. A Amazônia e a cobiça internacional. Rio de Janeiro: Civilização Brasileira, 1982, p. 52; ALDEN, Dauril, op. cit., 1974, p. 25-27; FARAGE, Nádia. As muralhas dos sertões: os povos indígenas no rio Branco e a colonização. Rio de Janeiro: Paz e Terra; ANPOCS, 1991, p. 39; COELHO, Mauro Cezar, op. cit., 2005, p. 230-243; ALMEIDA, Maria Regina Celestino de, op. cit., 1990, p. 124-134.
} 
cal. As informações reportadas pelo padre jesuíta João Daniel, ${ }^{20}$ juntamente com outras fontes, dão conta dessa questão. Do cultivo da mandioca saía o principal sustento da população. A partir de sua raiz faziam-se diferentes tipos de farinha, utilizadas para a produção de pães, bolos (chamados de beijus) e biscoitos. Em relação aos produtos do sertão, levando em consideração a caça e a pesca, havia um intenso consumo de peixes, quelônios e de outros gêneros pelos moradores. Das tartarugas, por exemplo, fazia-se a manteiga, muito consumida localmente. Da gordura e da calda do peixe-boi se podia fazer, respectivamente, manteiga e azeite, e de sua carne, semelhante à de porco, produziam-se linguiças, chouriços e paios. ${ }^{21}$ Os produtos extrativos e agrícolas eram também utilizados como forma de pagamento ao trabalho realizado pelos indígenas. ${ }^{22}$

Se atentarmos especificamente para as povoações de índios, locais onde os diretores desempenhavam sua função, constataremos a superioridade da atividade extrativa perante as demais. Nas décadas de 1760 e 1770, a maioria das povoações estava envolvida na extração de um ou mais gêneros. Entre os anos de 1755 a 1777, 70\% dos gêneros exportados por esses locais eram originários do extrativismo. ${ }^{23}$ Dispomos de dados para alguns anos que ratificam tais números: as informações contidas nos mapas das contas da Tesouraria do Comércio das Povoações de Índios, nas quais constam os rendimentos e despesas das vilas e lugares de índios do Estado do Grão-Pará e Rio Negro. Conseguimos situar os mapas para os anos de 1777 a 1781, 1788 e 1792.

\footnotetext{
${ }^{20}$ João Daniel, cronista da Companhia de Jesus, viveu na Amazônia entre os anos de 1741 a 1757, quando foi preso. No cárcere, o religioso escreveu sobre a riqueza hídrica e mineral e sobre a fauna e flora amazônica. Dentre outros pontos, registrou também questões acerca do solo, dos produtos do sertão e da agricultura, dos costumes indígenas e do seu contato com os não indígenas. As informações do jesuíta se constituem em fontes imprescindíveis para o estudo da sociedade amazônica do século XVIII.

${ }^{21}$ DANIEL, padre João. Tesouro descoberto no máximo rio Amazonas. v. 1. Rio de Janeiro: Contraponto, 2004, p. 413-419; 119-149; 513-597.

${ }^{22}$ Francisco Xavier de Mendonça Furtado. Lei régia. 03 maio 1757. DIRECTORIO que se deve observar... §§ 72-73. In: ALMEIDA, Rita Heloísa de, op. cit., 1997.

${ }^{23}$ COELHO, Mauro Cezar, op. cit,, 2005, p. 237; COSTA, Francisco de Assis, op. cit., 2010, p. 193-194.
} 


\section{Gráfico I \\ Rendimentos das povoações de índios do Estado do Grão-Pará e Rio Negro (em réis)}

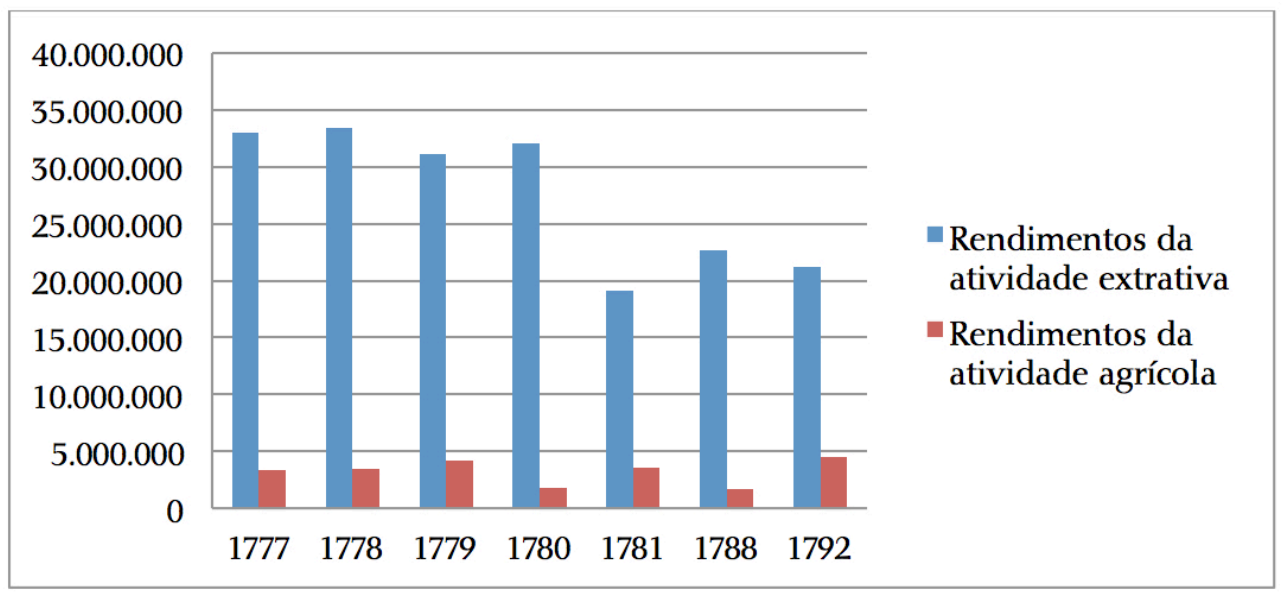

Fonte: Intendentes gerais do Pará. Mapa. 1777, 1778, 1779, 1780, 1781, 1788 e 1792. Mapa das Contas da Tesouraria do Comércio dos Índios. AHU, cx. 81, núm. 6648; cx. 88, núm. 7212; cx. 98, núm. 7790; cx.104, núm. 8205. Obs.: Nos rendimentos da atividade extrativa, estão incluídos os produtos da pesca.

Percebemos por meio da leitura do gráfico que os rendimentos oriundos do extrativismo, entre os anos de 1777 e 1780, foram superiores aos 30:000\$000 réis ${ }^{24}$ - número bem maior se comparado com as rendas provenientes da agricultura. Mesmo em 1781, 1788 e 1792, anos em que os rendimentos do extrativismo foram menores, tal atividade, em termos de renda, continuou significativamente superior à agricultura.

Em que pese tais considerações, é válido destacar que, em algumas povoações, os rendimentos agrícolas eram superiores ao do extrativismo. Referimo-nos às vilas de Chaves, Cintra e Colares, além dos lugares de São Bento do Capim, Santarém, Penhalonga, Barcarena, Condeixa, Rebordelo, Azevedo, Baião, Vilarinho do Monte e Gurupá. Já fora das povoações de índios, algumas regiões destacaram-se pela presença de engenhos de açúcar e de propriedades voltadas para o cultivo de arroz, tabaco, algodão e cacau, entre outros gêneros. Na Ilha Grande de Joanes, atual Ilha do Marajó, as fa-

\footnotetext{
${ }^{24}$ A disposição numérica obedece ao formato de valor encontrado na documentação.
} 
zendas de criação de gado vacum e cavalar tiveram grande importância para a economia da região, com larga utilização do escravo africano. ${ }^{25}$

Muitos diretores, então, encontravam-se em constante contato com produções extrativas e agrícolas dentro das povoações. E tais agentes não abriram mão de tirar proveito dessa situação, mesmo que para isso tivessem de transgredir. Alguns casos contidos em devassas ${ }^{26}$ demonstram esse tipo de situação.

Em povoação não identificada, a mulher do diretor José Félix Galvão de Araújo Oliveira realizava comércio com as índias do local, dando-lhes panos e recebendo em troca farinha. O diretor do Lugar de Azevedo, Alberto de Sousa Coelho, por meio do comércio com os índios, obtinha azeite de andiroba (gênero extrativo), cacau (gênero extrativo e agrícola), e farinha (gênero agrícola). Já a mulher do diretor da Vila de Esposende, Antônio José de Oliveira, solicitava das índias mandioca para fazer beiju. O diretor da Vila de Sousel, Eugênio Alvares da Câmara, em comércio com os indígenas, recebia cravos trazidos do sertão e, em troca, fornecia aguardente. Já o diretor da Vila de Alenquer, Domingos Xavier Alvares, e do Lugar de Santa Ana do Rio Capim, João Correa Abadinho, apropriavam-se da produção agrícola da povoação indevidamente. Por fim, o diretor de Salvaterra, Joaquim Duarte, dentre outras transgressões, usufruía para si de sal pertencente à povoação. ${ }^{27}$ Vimos, nesses exemplos, que uma maneira recorrente dos diretores disporem para si dos gêneros agrícolas e extrativos era por meio de trocas comerciais com os indígenas, prática que era condenada pelo Diretório. ${ }^{28}$

Ademais, ser diretor em determinadas povoações significava dispor de uma estrutura inacessível para muitos moradores. Afirma-se isto, pois o Diretório previa ser responsabilidade das câmaras, nas vilas, e dos principais,

\footnotetext{
${ }^{25}$ BEZERRA NETO, José Maia. Escravidão negra no Grão-Pará (séculos XVII-XIX). $2^{\mathrm{a}}$ ed. Belém: PakaTatu, 2012, p. 123-182.

${ }^{26}$ Nas devassas, de modo geral, constava o modo como os diretores, vigários e oficiais das povoações procediam no cargo. Também era feita referência aos rendimentos das roças do comum, a quanto de dízimos elas produziram, ao estado das casas, da igreja e das demais construções e dos bens existentes no interior das povoações.

${ }^{27}$ Autos de devassas. out. 1765. APEP, cód. 160, não numerado; 24 dez. 1764. APEP, cód. 160, núm. 08; $1^{\circ}$ set. 1767. APEP, cód. 160, não numerado; 12 dez. 1766. APEP, cód. 160, não numerado; 17 jan. 1767. APEP, cód. 160, não numerado; 23 mar. 1767. APEP, cód. 160, não numerado; 11 jan. 1767. APEP, cód. 160, não numerado; Paulo de Chaves Belo. 22 jul. 1780. Documento ao governador do Grão-Pará e Rio Negro, José de Nápoles Telo de Meneses. APEP, rolo 12, cód. 127, núm. 68, documentação microfilmada, Projeto Reencontro.

${ }^{28}$ Francisco Xavier de Mendonça Furtado. Lei régia. 3 maio 1757. DIRECTORIO que se deve observar nas Povoaçoens dos Índios... § 43. In: ALMEIDA, Rita Heloísa de, op. cit., 1997.
} 
nos lugares, preparar as canoas que iriam ao sertão coletar os gêneros silvestres, provendo-as "dos mantimentos necessários; e de tudo o mais, que for preciso". ${ }^{29}$ Porém, devido às dificuldades econômicas das povoações, esses custos acabaram ficando por conta da Tesouraria Geral dos Índios. Custos com os quais a maioria dos moradores não podia arcar devido aos seus baixos rendimentos econômicos. Além do mais, muitos deles não possuíam canoa - meio sem o qual era impossível tomar parte da atividade extrativa, de modo que "muito dificilmente participavam desse tipo de negócio".30

Já os diretores não se viam obrigados a arcarem, por conta própria, com uma expedição ao sertão saída das povoações, pois, conforme observado, as despesas que envolviam esse empreendimento ficavam por conta do Estado. E se para muitos moradores um dos empecilhos para a organização das expedições de coleta era a falta de canoa, alguns diretores poderiam tê-las nas próprias vilas e lugares em que atuavam. Esse foi o caso, por exemplo, dos diretores das povoações de Portel, Franca, Outeiro, Alenquer, Faro e Porto de Mós nos anos de 1765 e $1766 .^{31}$

Portanto, exercer a diretoria de uma vila ou lugar potencializava o usufruto dos produtos do sertão, sem custo algum, seja por meios previstos em lei ou não. Legalmente, os diretores tinham o direito de dispor da sexta parte de tudo o que fosse produzido na povoação, com exceção dos gêneros comestíveis. Ilegalmente, eles poderiam se apropriar dos produtos de coleta por meio de trocas comerciais com os indígenas, conforme os exemplos já demonstrados até aqui. A documentação também nos permitiu visualizar casos de diretores mandando indígenas ao sertão por conta própria, descumprindo assim, as normas do Diretório. Esse foi o caso do diretor da Vila de Sousel, Cosme Damião, denunciado pelo intendente-geral, Luís Gomes de Faria e Sousa, por mandar, juntamente com o vigário Alexandre Leal, dez índios ao sertão em proveito de ambos. De igual modo procedeu Henrique

${ }^{29}$ Francisco Xavier de Mendonça Furtado. Lei régia. 3 maio 1757. DIRECTORIO que se deve observar... §51. In: idem.

${ }^{30}$ ALMEIDA, Maria Regina Celestino de. A falácia do povoamento: ocupação portuguesa na Amazônia setecentista. In: COELHO, Mauro Cezar; GOMES, Flavio dos Santos; QUEIROZ, Jonas Marçal de; MARIN, Rosa Elizabeth Azevedo; PRADO, Geraldo (orgs.). Meandros da História: trabalho e poder no Pará e Maranhão, séculos XVIII e XIX. Belém: UNAMAZ, 2005, p. 31.

${ }^{31}$ Ver: Autos de devassas. 21 nov. /1765. APEP, cód. 160, não numerado; 30 dez. 1765. APEP, cód. 160 , não numerado; 19 nov. 1765. APEP, cód. 160, não numerado; 29 nov. 1765. APEP, cód. 160, não numerado; 12 dez. 1765. APEP, cód. 160, não numerado; 2 fev. 1766. APEP, cód. 160, não numerado. 
rev. hist. (São Paulo), n. 174, p. 101-129, jan.-jun., 2016 http://dx.doi.org/10.11606/issn.2316-9141.rh.2016.115846
Mauro Cezar Coelho e Vinícius Zúniga Melo

Nem heróis, nem vilões: o lugar dos diretores de povoaç̦ōes nas dinâmicas de transgressão à lei do Diretório dos Índios (1757-1798)

José de Vasconcelos, diretor da Vila de Santarém, responsável por mandar indígenas dessa povoação para o sertão. ${ }^{32}$

Os diretores poderiam obter vantagens também pela proximidade com os indígenas aldeados, haja vista que participavam de alguma forma de qualquer atividade que os envolvia. Assim, visando tirarem proveitos de tal proximidade, os diretores constantemente recorriam a práticas que infringiam a lei do Diretório. Para melhor dimensionarmos essa questão, vejamos alguns dados que mostram a importância do indígena no período aqui estudado.

Primeiro, os indígenas eram os trabalhadores preferenciais, senão exclusivos, das atividades extrativas. Segundo Heather Flynn Roller, "as expedições de coleta ocupavam a maior parte da mão de obra" do interior das povoações. ${ }^{33}$ Dentro desses espaços, os indígenas também eram utilizados como mão de obra na agricultura. Fora das povoações, tais agentes eram solicitados para trabalharem nas lavouras particulares, juntamente com o escravo africano. ${ }^{34}$ Eram requisitados para comporem as embarcações responsáveis pelas reais demarcações, na função de guias ou remeiros, para fazerem parte de comitivas cuja função era combater etnias inimigas dos portugueses e para trabalharem no serviço da Ribeira. ${ }^{35}$ Além destas, há um rol de outras atividades nas quais os indígenas eram fundamentais: trabalhavam na pesca, na caça, na carpintaria e nos serviços domésticos. ${ }^{36}$

Sendo assim, concordamos com parte da historiografia que afirma que os diretores, em vários momentos, beneficiavam-se do poder que possuíam

\footnotetext{
${ }^{32}$ Luís Gomes de Faria e Sousa. Por volta de 3 ago. 1761. Documento anexado ao ofício de Luís Gomes de Faria e Sousa, ao secretário de Estado da Marinha e Ultramar, Francisco Xavier de Mendonça Furtado, em 3 ago. 1761. AHU, cx. 50, núm. 4593; Auto de devassa. 11 jan. 1767. APEP, cód. 160, não numerado.

33 ROLLER, Heather Flynn. Expedições coloniais de coleta e a busca por oportunidades no sertão amazônico, c. 1750-1800. Revista de História. São Paulo: fasc. 168, 2013, p. 207.

34 Sobre a importância da presença escrava negra no Pará, inclusive durante a vigência do Diretório dos Índios, ver: BEZERRA NETO, José Maia, op. cit., 2012, p. 48-64.

35 Matias José Ribeiro. 21 nov. 1783. Documento ao secretário de Estado da Marinha e Ultramar, Martinho de Melo e Castro. AHU, cx. 90, núm. 7366; Joaquim José Pereira Bittencourt. 28 maio 1785. Documento ao tenente coronel comissário, João Baptista Mardel. APEP, rolo 13, cód. 429, núm. 02, documentação microfilmada, Secretaria da Capitania; Manuel da Gama Lodo de Almada. 13 jul. 1790. Documento a Henrique João Wilckens. APEP, rolo 13, cód. 429, núm. 137, documentação microfilmada, Secretaria da Capitania; Francisco Jose Brandão de Castro. 22 maio 1792. Documento ao Juiz ordinário de Cametá. APEP, rolo 14, cód. 496, núm. 61, documentação microfilmada, Secretaria da Capitania; João Pereira Caldas. 07/02/1776. Documento a Manoel da Gama Lobo de Almada. APEP, cód. 291, núm. 291, documentação digitalizada. 36 SOUZA JÚNIOR, José Alves de, op. cit., 2009, p. 13; FERREIRA REIS, Arthur Cezar, op. cit., 1982, p. 53.
} 
em relação ao indígena para usufruírem de sua força de trabalho, mesmo que para isso descumprissem os dispositivos legais. Vejamos alguns casos a seguir que retratam esse tipo de situação.

Segundo Paulo Chaves Belo, intendente-geral, o diretor de Salvaterra, Joaquim Duarte, mantinha em sua residência índias solteiras e casadas e as aplicava nos serviços de seus interesses. A mulher do diretor da Vila de Melgaço, o já citado Félix Galvão de Araújo, utilizava índios e índias em suas roças. Na devassa tirada a respeito do também já citado diretor Cosme Damião da Silva, consta que ele se utilizou de indígenas da povoação que dirigia, em sua lavoura particular de algodão. Os indígenas da Vila de Borba, a nova, enviaram um requerimento ao secretário de Estado da Marinha e Ultramar, Tomé Joaquim da Costa Corte Real, acusando o diretor da povoação, Luís da Cunha de Eça e Castro, de utilizá-los, violentamente, em seus serviços particulares. O diretor da Vila de Alter do Chão, João Francisco Furtado, por meio de uma devassa, foi denunciado por usufruir de uma indígena da povoação em suas lavouras. Por fim, em devassa tirada sobre o diretor da Vila de Santarém, Henrique José de Vasconcelos, consta que a sua mulher utilizava-se do trabalho de indígenas. ${ }^{37}$

Além dessas, é possível visualizar outras transgressões praticadas em relação à população aldeada: diretores agindo com violência junto aos indígenas da povoação, diretores não efetuando ou retendo para si pagamentos destinados aos seus tutelados e diretores concedendo indígenas aos moradores à revelia da lei. ${ }^{38}$

\footnotetext{
${ }^{37}$ Paulo de Chaves Belo. 22 jul. 1780. Documento ao governador do Grão-Pará e Rio Negro, José de Nápoles Telo de Meneses. APEP, rolo 12, cód. 127, núm. 68, documentação microfilmada, Projeto Reencontro; Índios da Vila de Borba, a nova. Requerimento. Posteriormente a 1759. Requerimento ao secretário de Estado da Marinha e Ultramar, Tomé Joaquim da Costa Corte Real. AHU, cx. 45, núm. 4141; autos de devassas. 11 out. 1765. APEP, cód. 160, não numerado; 22 dez. 164. APEP, cód. 160, núm. 02; 9 jan. 1766. APEP, cód. 160, não numerado; jan. 1767. APEP, cód. 160, não numerado.

${ }^{38}$ Autos de devassas. 27 dez. 1764. APEP, cód. 160, núm. 07; 1765. APEP, cód. 160, não numerado; Paulo de Chaves Belo. 22 jul.1780. Documento ao governador do Grão-Pará e Rio Negro, José de Nápoles Telo de Meneses. APEP, rolo 12, cód. 127, núm. 68, documentação microfilmada, Projeto Reencontro; Autos de devassas. 17 jan. 1767. APEP, cód. 160, não numerado; 24 dez. 1764. APEP, cód. 160, núm. 08; 30 dez. 1766. APEP, cód. 160, não numerado; out. 1765. APEP, cód. 160, não numerado; Auto de devassa. $1^{\circ}$ set. 1767. APEP, cód. 160, não numerado. É importante destacar que o uso da violência pelo diretor em relação ao indígena era um tipo de comportamento reprovado pela lei do Diretório, pois esta, conforme já foi observado, determinava uma tutela branda e suave. Ver: Francisco Xavier de Mendonça Furtado. Lei régia. 3 maio 1757. DIRECTORIO que se deve observar... § 14. In: ALMEIDA, Rita Heloísa de, op. cit., 1997.
} 
Elencar as práticas transgressoras dos diretores de povoações não significa dizer, é bom deixar claro, que compartilhamos o argumento, de que tais agentes foram responsáveis pelo fracasso do Diretório dos Índios. Ao contrário: o objetivo a que nos propomos é justamente problematizar tal interpretação. O destaque a essas transgressões ocorre na medida em que tais práticas nos ajudam a perscrutar o universo socioeconômico dos diretores dentro das povoações de índios. Sendo assim, conforme evidenciado, muitos diretores atuavam em vilas e lugares com produções extrativas, agrícolas e com mão de obra indígena, os quais, devido a sua importância, se constituíam em fontes de riqueza local. Eles estavam também envolvidos diretamente com cada uma dessas atividades e com essa força de trabalho. E, partindo-se da leitura documental, concordamos com parte da historiografia referente ao Diretório no Vale Amazônico, de que os diretores se valiam dos poderes que possuíam nas povoações para se apropriarem dos gêneros de coleta, de cultivo e do trabalho indígena por meios não apenas previstos na lei, mas também, e sistematicamente, mediante transgressões.

Distinguimo-nos daquela produção pelo fato de não vermos nas práticas transgressoras dos diretores um dos principais motivos que levaram ao fracasso do Diretório dos Índios - no entanto, essa é uma questão à qual voltaremos com maior profundidade no tópico seguinte. Além disso, a proximidade dos diretores em relação a importantes fontes de riqueza local nos revela apenas um dos aspectos que podiam caracterizar o universo socioeconômico dos diretores. Em outras palavras, do mesmo modo que a documentação indica que o dia a dia desses agentes, nas povoações, podia ser marcado pelos dividendos da proximidade com os indígenas aldeados e com os produtos extrativos e agrícolas, ela também aponta para o fato de que o ocupante de uma diretoria podia se deparar com diferentes tipos de empecilhos, inclusive com o baixo número de indígenas e, consequentemente, com baixos rendimentos em determinada vila ou lugar. Para além dessas precariedades, os diretores se queixavam das fugas e revoltas indígenas e também de suas baixas remunerações.

Em uma consulta do Conselho Ultramarino, são citados os "contínuos perigos de vida" e a má remuneração com a qual Bernardo Toscano de Vasconcelos teve que conviver ao exercer as diretorias de várias vilas. Um exemplo das condições possíveis vividas pelos diretores pode ser percebido em uma devassa havida em Alenquer. Nela, reporta-se um incêndio provocado por dois rapazes que destruiu algumas casas e igreja da vila, as farinhas dos dízimos e mais alguns mantimentos da canoa que iria descer ao sertão. Em função do ocorrido, o diretor e sua família tiveram seus pertences perdidos, 
tendo que solicitarem abrigo nas casas dos indígenas, enquanto reconstruíam-se as edificações. Há, também, o caso do diretor Sérgio Justiniano de Figueiredo que entrou em conflito com o cabo de canoa devido ao número excessivo de indígenas que este agente levava na embarcação da povoação com destino à Tesouraria Geral dos Índios. Em vista dessa situação, o diretor afirmou que na expedição iriam somente os índios necessários e que o restante ficaria na povoação, trabalhando nas roças do comum. $\mathrm{O}$ intendente-geral, Matias José Ribeiro, responsabilizava a omissão dos diretores pela estagnação das povoações do Pará e de suas atividades agrícolas, mas também a retirada constante de indígenas para comporem as embarcações responsáveis pelas reais demarcações em Mato Grosso e Rio Negro. ${ }^{39}$

As revoltas e insurgências dos índios aldeados constituíam outra ordem de dificuldades para os diretores. José Alves de Souza Júnior, mesmo considerando trágica para os indígenas a mudança da tutela religiosa pela tutela laica do Diretório, aborda as reclamações dos diretores em relação à falta de autoridade sobre os índios e das violências que deles sofriam. ${ }^{40} \mathrm{Em}$ meio à documentação, encontramos casos que corroboram este cenário. O tenente de infantaria Caetano de Freitas da Costa, em expedição à Vila de Colares, foi controlar uma sublevação indígena ocorrida no local. Segundo o tenente, os indígenas tinham matado o principal da povoação e agiram "Armados, absolutos, e dezobedientes ao seu Director". O diretor da Vila de Cintra, José Antônio da Costa Corte Real, fez reclamações dos indígenas da povoação ao governador José de Nápoles Telo de Menezes: alguns deles, por se encontrarem em um terço de auxiliares, não se viam na obrigação de servirem à diretoria da vila e se consideravam isentos dos demais serviços, de modo que os filhos destes mesmos índios levavam uma vida de "vadiagem" na localidade. Já o comandante e porta-bandeira, Francisco José Brandão de Castro, denunciava os transtornos causados pelos índios Mundurucu na localidade de Arapary: medo na população, que evitava trabalhar na agricultura, e, consequentemente, potencialização dos prejuízos da seca. Em devassa tirada na Vila de Sousel, consta que, quando o diretor José Caetano Ferreira

\footnotetext{
${ }^{39}$ Conselho Ultramarino. Consulta. 22 dez. 1778. Em anexo ao requerimento de Bernardo Toscano de Vasconcelos à rainha D. Maria I, em $1^{\circ}$ jun. 1779. AHU, cx. 83, núm. 6783; Auto de devassa. 29 nov. 1765. APEP, cód. 160, não numerado; Sérgio Justiniano de Figueiredo. 27 set. 1796. Não foi possível identificar o destinatário. APEP, rolo 12, cód. 126, núm. 109, documentação microfilmada, Projeto Reencontro; Matias José Ribeiro. Ofício. 21 nov. 1783. Ofício ao secretário de Estado da Marinha e Ultramar, Martinho de Melo e Castro. AHU, cx. 90, núm. 7366.

40 SOUZA JÚNIOR, José Alves de, op. cit., 2009, p. 272-273.
} 
nomeava alguns indígenas para desempenharem serviços, o principal da povoação os instruía a fugirem e refugiarem-se em sua roça. Por mais que a Vila de Portel fosse populosa, em devassa tirada, é afirmado que os indígenas desse local nunca compareciam na povoação e nem se dirigiam à igreja, sendo desobedientes ao seu diretor, além de fugirem dos reais serviços. ${ }^{41}$

Uma reclamação recorrente de diretores relacionava-se à pobreza das povoações. Podemos observar os tutores dos índios fazendo referências à falta de ferramentas, aos parcos resultados agrícolas, ao baixo número de indígenas e ao estado precário das casas das povoações que dirigiam.

O diretor de Santarém Novo, João da Silva Coelho, em carta enviada ao governador do Estado do Grão-Pará e Rio Negro, Francisco de Sousa Coutinho, reclamava da falta de ferramentas necessárias para a feitura dos roçados. Em vista dessa adversidade, João Coelho pedia ao governador a saída do cargo de diretor. O diretor interino da Vila de Chaves, Manuel Antônio Pantoja, destacava ao mesmo governador a falta de ferramentas e os parcos resultados agrícolas da povoação que dirigia. Manuel Pantoja que, segundo ele, fora "obrigado" pelo comandante "a servir interinamente o cargo", afirmava que o algodão colhido não prestava para nada, pois se encontrava todo coberto de mato. Em relação à farinha, os indígenas teriam demorado um mês para colher apenas sete alqueires ao todo. No fim, afirmava que "nada ha a esperar desta Vila". Já o diretor de Alcobaça, Bento Ribeiro, reclamava junto a Souza Coutinho que a dita povoação ficava quase sem utilidade para sua majestade com a ausência de índios. Por fim, citamos o caso do diretor da povoação de Porto Salvo, Tomé Joaquim de Siqueira. Em carta enviada ao governador Sousa Coutinho, Siqueira reportava o estado de ruínas em que se encontravam as casas de índios e vigários e apontava para o problema da falta de gente para lhe ajudar em seus serviços. É possível observar na documentação também outras carências que algumas vilas ou lugares ao tempo do Diretório poderiam ter, como a falta de canoas e até mesmo de papel. ${ }^{42}$

\footnotetext{
${ }^{41}$ Caetano de Freitas da Costa. 30 set. 1777. Em anexo ao requerimento de Manoel Carvalho dos Santos, à rainha d. Maria I, em 8 out. 1777. AHU, cx. 78, núm. 6460; José Antônio da Costa Corte Real. 21 jul. 1780. Documento enviado ao governador do Grão-Pará e Rio Negro, José de Nápoles Telo de Meneses. APEP, rolo 12, cód. 127, núm. 67, documentação microfilmada, Projeto Reencontro; Francisco José Brandão de Castro. 28 maio 1792. Documento enviado ao governador do Grão-Pará e Rio Negro, d. Francisco de Sousa Coutinho. APEP, rolo 14, cód. 496, núm. 63, documentação microfilmada, Secretaria da Capitania; Autos de devassas. 25 out. 1768. APEP, cód. 160, não numerado; 15 out. 1768. APEP, cód. 160, não numerado.

${ }^{42}$ João da Silva Coelho. 24 ago. 1796. Documento ao governador do Grão-Pará e Rio Negro, Francisco de Sousa Coutinho. APEP, rolo 12, cód. 126, núm. 72, documentação microfilma-
} 
Esses empecilhos encontrados no dia a dia das povoações prejudicavam o cumprimento das funções dos diretores. Com a falta de ferramentas necessárias para a formação dos roçados, eles se viam prejudicados na incumbência de estimularem a produção agrícola. A falta de canoa na povoação era um empecilho para a realização da atividade extrativa, por ser ela o meio de locomoção utilizado para descer os rios e coletar os gêneros da floresta. Consequentemente, o comércio desses gêneros, que também era responsabilidade do diretor incentivar, ${ }^{43}$ poderia sofrer prejuízo. Já o baixo número de índios dentro das vilas e lugares acarretava, por exemplo, falta de mão de obra necessária para a feitura das roças, construção de prédios e para o transporte de madeira.

Entretanto, não seria exagero suspeitarmos do discurso de diretores que reclamavam da falta de mão de obra indígena no interior das povoações que dirigiam. Por exemplo, vimos o caso de Sérgio Justiniano de Figueiredo que, pensando na força de trabalho indispensável para a atividade agrícola na povoação, entrou em conflito com o cabo de canoa, pois este queria levar consigo mais índios que o necessário. Porém, essa insatisfação demonstrada pelo diretor poderia expressar muito mais um descontentamento em relação à diminuição do número de índios que ficaria a seu dispor do que a falta de indivíduos para trabalhar nos serviços da povoação. A despeito de tal observação, é certo, também, que alguns autores trabalham com a tese de que foi essa constante retirada de indígenas das povoações, por indivíduos da administração colonial, um dos motivos que levaram à não concretização de vários dos dispositivos do Diretório e ao seu consequente fracasso. ${ }^{44}$ Vimos,

da, Projeto Reencontro; Manuel Antônio Pantoja. 25 ago. 1796. Documento ao governador Grão-Pará e Rio Negro, Francisco de Sousa Coutinho. APEP, rolo 12, cód. 126, núm. 73, documentação microfilmada, Projeto Reencontro; Bento Ribeiro. 3 jul. 1796. Documento ao governador do Grão-Pará e Rio Negro, Francisco de Sousa Coutinho. APEP, rolo 12, cód. 126, núm. 54, documentação microfilmada, Projeto Reencontro; Tomé Joaquim de Siqueira. 7 jun. 1796. Documento ao governador do Grão-Pará e Rio Negro, Francisco de Sousa Coutinho. APEP, rolo 12, cód. 126, núm. 51, documentação microfilmada, Projeto Reencontro; Manoel Antônio Furtado 10 maio 1790. Documento ao sargento-mor comissário. APEP, rolo 13, cód. 429, núm. 94, documentação microfilmada, Secretaria da Capitania; José Manuel de Moraes. 1793. Documento ao sargento-mor segundo comissário. APEP, rolo 14, cód. 496, núm. 163, documentação microfilmada, Secretaria da Capitania; Joaquim José Pereira Bittencourt. 28 maio 1785. Documento ao tenente coronel comissário, João Baptista Mardel. APEP, rolo 13, cód. 429, núm. 02, documentação microfilmada, Secretaria da Capitania.

${ }^{43}$ Francisco Xavier de Mendonça Furtado. Lei régia. 03 maio 1757. DIRECTORIO que se deve observar... §§ 46-58. In: ALMEIDA, Rita Heloísa de, op. cit., 1997.

${ }^{44}$ ALMEIDA, Maria Regina Celestino de, op. cit., 1990, p. 129-134; ALMEIDA, Rita Heloísa de, op. cit., 1997, p. 331; PRADO JÚNIOR, Caio Prado, op. cit., 2011, p. 99-100. 
inclusive, a queixa de um intendente ao afirmar que um dos motivos para o não crescimento agrícola das povoações residia na constante retirada de indígenas para as embarcações das reais demarcações.

De toda forma, alguns aspectos da sociedade de então apontam para outros percalços no exercício das diretorias. Para conhecê-los, voltemos à análise dos mapas das contas da Tesouraria do Comércio dos Índios dos anos de 1777 a 1781, 1788 e 1792, nos quais constam os rendimentos e as despesas das vilas e lugares de índios do Estado do Grão-Pará e Rio Negro. Vejamos alguns números para três anos não consecutivos. Em 1778, das trinta e oito vilas, duas não tiveram rendimentos da atividade extrativa. Já em relação aos trinta e nove lugares, 14 deles não conseguiram obter renda alguma da coleta. Em se tratando do ano de 1788, o quadro é um pouco mais grave. Das trinta e nove vilas existentes, quinze não tiveram rendimentos com os produtos do sertão, enquanto dos trinta e sete lugares, vinte e nove, a grande maioria, não conseguiram obter renda do extrativismo. Acerca do ano de 1792, o mapa não distingue as vilas dos lugares. Portanto, das sessenta e cinco povoações existentes no Grão-Pará e Rio Negro naquele ano, doze não tiveram nenhum rendimento fruto da coleta. Esses dados significam dizer que os diretores dessas povoações onde não houve nenhum ganho com o extrativismo, incluindo a pesca, não receberam a sexta parte dos gêneros do sertão a que tinham direito.

Ainda por meio da análise desses mapas, é possível detectar povoações na capitania do Pará que, por mais de um ano, não somente não obtiveram rendimentos do extrativismo, como também da agricultura. Esse foi o caso dos lugares de Ourém e Porto Grande em todos os sete anos para os quais a pesquisa dispõe dos mapas, e do lugar de Gurupá, para os anos de 1778, 1779, 1780, 1781 e 1788. Os lugares de Carrazedo, São Bento do Capim e Penhalonga ficaram sem rendimentos extrativos e agrícolas em quatro anos diferentes, e a Vila de Colares, em três. Portanto, esses números demonstram que os diretores dessas povoações não somente deixaram de receber os gêneros do sertão, mas também os agrícolas a que tinham direito como forma de seu pagamento. Porém, tais dados necessariamente não significam dizer que esses mesmos diretores não usufruíram de nenhuma forma daqueles produtos. Considerando o que os documentos apontam, é possível que eles os tenham adquiridos por meio de transgressões, seja pelas trocas comerciais com os indígenas, seja pela apropriação indevida da produção.

As dificuldades aqui destacadas acabam por sopesar os benefícios que a função de diretor poderia trazer a seu ocupante. Se, por um lado, muitos diretores tiravam proveito por atuarem em povoações com importante presença de 
indígenas e de gêneros de cultivo e de coleta, por outro, vários desses agentes tinham que conviver com diferentes dificuldades dentro das vilas e lugares. Considerar esses empecilhos se faz importante, pois indicam que nem sempre era algo cômodo e absolutamente vantajoso exercer uma diretoria. Alguns ocupantes desse cargo lidavam com a falta de indígenas, de canoas, com parcos resultados agrícolas e extrativos, além de terem de conviver com a possibilidade sempre constante de revoltas provocadas pela população aldeada.

\section{Nem vilões nem mocinhos: um novo sentido para as transgressões dos diretores}

A historiografia a que nos referimos no início deste artigo elege os diretores como um dos grandes "vilões" do Diretório. Segundo tal interpretação, suas transgressões, relacionadas de modo geral aos índios aldeados, foram determinantes para a existência de um fracasso dos objetivos daquela lei. Entretanto, é importante destacar que não apenas os diretores cometeram desvios: outros agentes descumpriram as normas do Diretório visando auferir vantagens. ${ }^{45} \mathrm{E}$ tal como ocorreu com os desvios dos diretores, muitos daqueles descumprimentos visavam o acesso a gêneros agrícolas, extrativos e de mão de obra indígena. Destaca-se também que normalmente mais de um sujeito estava envolvido diretamente nos descumprimentos.

Em devassa tirada na Vila de Sousel, afirma-se que o vigário dessa povoação recebia dos indígenas, em troca de aguardente, gêneros do sertão. O também vigário de Sousel, Alexandre Leal (o qual, conforme já indicado, junto com o diretor dessa vila levou por sua conta dez indígenas ao sertão), enviou uma canoa equipada para fazer a extração de cravo. O intendente-geral do Pará, João de Amorim Pereira, dirigiu críticas aos vigários das povoações, acusando-os de exercerem o governo temporal das índias solteiras e de nelas aplicarem castigos quando trabalhavam em suas próprias roças ou nas roças do comum. Já o cabo de canoa da Vila de Melgaço, segundo o ouvidor geral do Pará, é suspeito de estar envolvido na fuga de centenas de indígenas da povoação. Por sua vez, o cabo de canoa de Pinhel, de acordo com devassa tirada, agia violentamente contra os índios da vila. Os cabos das vilas de Sousel, Melgaço, Oeiras, Colares e Conde forneceram ao diretor do Gurupá,

\footnotetext{
${ }^{45}$ É importante destacar que José Alves de Souza Júnior já aponta em seu trabalho infrações à lei do Diretório, relacionadas aos povos indígenas, cometidas por vigários, principais e intendentes. SOUZA JÚNIOR, José Alves de, op. cit., 2009, p. 275-276; 286-288; 292-295.
} 
Clemente de Almeida Pereira, potes de manteiga extraída do sertão. Além desse desvio, todos esses cabos cometeram outros, como o caso de Lourenço da Costa, da Vila de Colares, que coletou para si onze potes de manteiga. ${ }^{46}$

A documentação também demonstra transgressões realizadas pelos principais das povoações. Enquanto o chefe indígena do Lugar de Outeiro não realizava, igualitariamente, a repartição dos índios para os serviços dos moradores, o principal da Vila de Esposende, segundo devassa feita na povoação, castigava os indígenas do local. Por sua vez, o principal do Lugar de Azevedo foi beneficiado pelo recebimento de indígenas do diretor dessa povoação, Alberto de Sousa Coelho. Já o soldado Francisco José, dispunha em sua casa de uma índia da Vila de Alter do Chão. O governador da capitania do Rio Negro, Joaquim de Melo e Povoas, denunciou que quatro soldados desertores se utilizaram de indígenas pescadores que pertenciam ao diretor de Airão. O soldado José Duarte, na Vila de Santarém, vendia aguardente aos indígenas da povoação e, em troca, por cada frasco, recebia 400 réis ou farinha. Já Manuel Corrêa Picanço, morador de Santarém, recebeu do diretor da Vila de Alenquer, farinha pertencente a essa povoação. Simão Borges, por sua vez, obteve dos indígenas gêneros coletados no sertão com a anuência do cabo de canoa. Por fim, as roças do Lugar de Santa Ana do Rio Capim foram administradas por dois capitães, os quais, juntamente com o diretor, o vigário e os indígenas da povoação, consumiram toda a farinha que nelas foram produzidas. ${ }^{47}$

Como se pode notar, as transgressões aos dispositivos legais eram recorrentes. Os diretores as realizavam, mas não eram os únicos. Vigários,

\footnotetext{
${ }^{46}$ Auto de devassa. 12 dez. 1766. APEP, cód. 160, não numerado; Luís Gomes de Faria e Sousa. Por volta de 3 agosto de 1761. Em anexo ao ofício de Luís Gomes de Faria e Sousa ao Secretário de Estado da Marinha e Ultramar, Francisco Xavier de Mendonça Furtado, em 3 de agosto de 1761. AHU, cx. 50, núm. 4593; João de Amorim Pereira. Ofício. 15 maio 1767. Ofício enviado a Francisco Xavier de Mendonça Furtado, Secretário de Estado da Marinha e Ultramar. AHU, cx. 60, núm. 5352; João Francisco Ribeiro. 24 jun. 1779. Documento ao governador do Grão-Pará e Maranhão, João Pereira Caldas. APEP, cód. 352, núm. 57, documentação digitalizada; Auto de devassa. 5 jan. 1766. APEP, cód. 160, não numerado; Luís Gomes de Faria e Sousa. Por volta de 3 agosto de 1761. Em anexo ao ofício de Luís Gomes de Faria e Sousa, ao secretário de Estado da Marinha e Ultramar, Francisco Xavier de Mendonça Furtado, em 3 agosto de 1761. AHU, cx. 50, núm. 4593.

${ }^{47}$ Autos de devassas. 9 nov. 1765. APEP, cód. 160, não numerado; 19 nov. 1765. APEP, cód. 160, não numerado; 24 dez. 1764. APEP, cód. 160, núm. 8; nov. 1765. APEP, cód. 160, não numerado; 20 jan. 1766. APEP, cód. 160, não numerado; Joaquim de Mello e Povoas. 24 abr. 1759. Documento enviado ao governador do Grão-Pará e Maranhão, Francisco Xavier de Mendonça Furtado. APEP, cód. 96, núm. 07, documentação digitalizada; Autos de devassas. 5 jan. 1766. APEP, cód. 160, não numerado. 17 jan. 1767. APEP, cód. 160, não numerado; 19 nov. 1765. APEP, cód. 160, não numerado; 23 mar. 1767. APEP, cód. 160, não numerado.
} 
cabos de canoa, principais, soldados e demais moradores também cometiam ações desviantes, buscando, muitas vezes, apropriarem-se dos produtos extrativos, agrícolas e da mão de obra indígena. Dessa forma, a documentação demonstra que descumprir a lei era o horizonte possível para muitos dos sujeitos do Vale Amazônico ao tempo da segunda metade do século XVIII. Vejamos melhor tal questão.

Como foi demonstrado, os gêneros extrativos e agrícolas tinham importância tanto externa quanto interna. Ambos compunham as pautas de exportação do Estado e eram consumidos largamente na região. As povoações, normalmente, eram locais de produção desses gêneros. Porém, tal produção destinava-se à Tesouraria Geral dos Índios ou ao abastecimento da capitania do Rio Negro, da cidade de Belém, das tropas militares e de expedições, fossem elas designadas às reais demarcações, ao combate de etnias indígenas inimigas dos portugueses ou à coleta dos gêneros do sertão.

Os indígenas aldeados constituíam-se como a mão de obra principal, senão exclusiva, para a atividade de coleta. Eram também solicitados para uma série de outros serviços, dentre eles, a agricultura. No entanto, a escravização dos indígenas durante a vigência do Diretório, por mais que esses agentes geralmente estivessem em bom número nas vilas e lugares, era proibida, e o acesso dos moradores à sua força de trabalho era condicionado. Sendo assim, durante o período, houve um intenso conflito entre moradores e a administração colonial em torno do trabalho indígena. Além do mais, os moradores tiveram reduzidas suas parcelas no usufruto dessa mão de obra, pois quem mais a utilizou foi a metrópole, a fim de pôr em prática os planos que tinha para a região. O Diretório, por fim, ainda colocou mais um sujeito na disputa em torno do trabalho indígena: os principais, reconhecidos pela lei. ${ }^{48}$

Em vista dessas limitações de acesso tanto ao indígena quanto aos produtos de cultivo e de coleta, muitos foram os diretores, conforme visto no tópico anterior, que se aproveitaram da proximidade com essas fontes de riqueza e do poder que a lei lhes dava em relação a elas, para se beneficiarem de maneira transgressora. No entanto, o ponto é que tal beneficiamento por meio de infrações ao Diretório não se restringia apenas aos tutores dos índios. É verdade que outros agentes podiam não ter as mesmas atribuições que os diretores, o que lhes colocava em uma posição central para o cumprimento ou não das diretrizes metropolitanas nas diversas povoações

${ }^{48}$ COELHO, Mauro Cezar, op. cit., 2005, p. 224-259. 
que compunham o Vale Amazônico. Ainda assim, esses outros agentes efetuaram transgressões, de modo que elas poderiam se mostrar tão danosas quanto as realizadas pelos diretores.

Afirma-se isso, primeiro, porque vigários, principais, cabos de canoa, soldados e demais moradores, na medida em que residiam permanentemente nas vilas e lugares, ou que ao menos transitavam em meio a esses espaços, também estavam em constante contato com as fontes de riqueza produzidas. Em segundo lugar, as transgressões desses outros agentes, muitas das vezes, tinham os mesmos objetivos das que eram realizadas pelos diretores: a apropriação dos produtos agrícolas, extrativos e do trabalho indígena. E, em terceiro, conforme visto nos exemplos aqui citados, muitas infrações dos diretores não eram realizadas solitariamente. Pelo contrário: eles não somente contavam com a participação de outros indivíduos, mas também com a direta colaboração deles. Isso está claro, por exemplo, na necessária relação que o diretor Clemente Pereira teve de manter com diferentes cabos de canoa para se beneficiar da manteiga extraída no sertão. Dessa forma, é muito pouco provável que as transgressões dos diretores pudessem se efetivar sem a sistemática concorrência de outros agentes, tornando impossível a afirmação de responsabilidades preponderantes.

Vistas essas considerações, retomemos a problematização em torno da ideia de que os diretores foram responsáveis pelo fracasso do Diretório dos Índios. Tal argumento, a nosso ver, não se fundamenta na análise das diretorias, mas na incorporação da crítica coeva. Em relação à análise das diretorias, vimos no tópico anterior alguns dos empecilhos que muitos ocupantes do cargo enfrentavam, os quais dificultavam a execução de suas atribuições, limitavam suas capacidades de ganho de forma transgressora, além de se mostrarem inerentes às povoações de índios, ou pelo menos a algumas delas: escassez de produção agrícola e extrativa, utilização do indígena em serviços do Estado e a possibilidade sempre iminente de revoltas indígenas.

Em relação ao contexto no qual foram formuladas as críticas em torno dos diretores, e no qual as suas transgressões se deram, é importante levar em consideração que, conforme foi visto, não foram apenas eles que infringiram a lei do Diretório. Pelo contrário: em face de sua ocorrência sistemática entre os mais diferentes agentes, a transgressão nessa sociedade não se constituía em exceção, mas, sim, em regra. Era uma prática que fazia parte da ordem das coisas, de igual modo como apontam Paulo Cavalcante e Ernst Pijning para a América portuguesa como um todo, ao estudarem, respectivamente, 
a sociedade mineira da primeira metade do século XVIII e o contrabando praticado nesse mesmo século no Rio de Janeiro e no Atlântico Sul. ${ }^{49}$

É importante destacar que as transgressões mostravam-se ser a regra no Vale Amazônico da segunda metade do século XVIII, pois tal constatação, a nosso ver, ajuda a repensar até que ponto é significativo atentar para o grau de sucesso obtido pelo Diretório dos Índios e a parcela de interferência dos diretores nesse desfecho. Não que as suas infrações não possam ter prejudicado os rumos dessa lei - mas esse juízo já foi feito pelos próprios contemporâneos aos diretores.

A partir do momento em que se nota que os diretores estavam longe de serem os únicos que infringiam os dispositivos legais e que os desvios dos demais agentes possuíam, muitas das vezes, a mesma finalidade dos que eram praticados pelos tutores dos índios, concluímos que o melhor caminho é compreender o motivo que levava diretores, cabos de canoa, vigários, principais e uma série de outros moradores a agir de tal maneira. A conclusão a que chegamos é que todos esses agentes viam nas transgressões um meio fundamental para dispor dos produtos extrativos, agrícolas e da mão de obra indígena, os quais, por serem fontes de riqueza local, eram indispensáveis na sociedade da qual faziam parte, na medida em que eram utilizados na alimentação, na vestimenta, na fabricação de canoa, no comércio, na remuneração... É em razão disso que a infração ao Diretório ocorria sistematicamente, de modo que não dá para calcular, ratifica-se, de quem era o desvio mais prejudicial. Muitos agentes coloniais não estavam dispostos a abrir mão da transgressão, mesmo que ela se mostrasse danosa aos interesses metropolitanos.

Ademais, a própria ideia de fracasso é uma questão a ser questionada. Não a enfrentaremos aqui, pois ela ultrapassa os limites do texto. De todo modo, importa ressaltar que muitos dos dispositivos do Diretório foram retomados tanto pela carta régia de 1798 quanto por políticas indigenistas formuladas no século XIX, pelo Império do Brasil..50

\footnotetext{
${ }^{49}$ CAVALCANTE, Paulo. Negócios de trapaça: caminho e descaminhos na América Portuguesa (1700-1750). Tese de doutorado, História, Programa de Pós-Graduação em História Social, Universidade de São Paulo, 2002, p. 24-25; PIJNING, Ernst. Contrabando, ilegalidade e medidas políticas no Rio de Janeiro do século XVIII. Revista Brasileira de História. São Paulo, v. 21, fasc. 42, 2001, p. 397-414.

50 SOUSA, Eveline Almeida de. Os ideais de civilização na Amazônia imperial (1845-1889). Dissertação de mestrado, História, Programa de Pós-Graduação em História Social da Amazônia, Universidade Federal do Pará, 2011; LOPES, Patricia Raiol Castro de Melo. Os corpos de trabalhadores na província do Grão-Pará: Outros significados para uma política de arregimentação da mão de obra (18351840). Dissertação de mestrado em História, Programa de Pós-Graduação em História Social da Amazônia, Universidade Federal do Pará, 2012.
} 
E se diretores, principais, vigários, cabos de canoa, entre outros, utilizavam-se dos recursos que dispunham para obter ganhos próprios, mesmo que para isso cometessem práticas desviantes, o mesmo se pode falar dos indígenas aldeados. Há uma rica documentação em que se encontram indícios de que esses indígenas descumpriam os dispositivos legais com vista à obtenção de benefícios, conforme foi aqui destacado. Tais indícios, aliados a uma bibliografia que destaca o papel de protagonista desempenhado por esses agentes em meio à sociedade do Diretório, ${ }^{51}$ nos fazem pensar que dificilmente os descumprimentos à lei por parte dos diretores em relação à população aldeada se dessem apenas por meios coativos e que viessem a atender apenas aos interesses de um dos lados. As relações comerciais entre diretores e indígenas é um bom exemplo. A documentação referida anteriormente demonstra que estes não forneciam gêneros agrícolas e extrativos a seus tutores a troco de nada. Pelo contrário: recebiam deles produtos de seus interesses, como aguardentes e panos de algodão ou de linho. Portanto, conforme argumenta Patrícia Sampaio, ${ }^{52}$ quando os indígenas realizavam o comércio, fugiam das povoações, mostravam-se avessos aos serviços a que foram designados e agiam de maneira violenta contra os diretores para satisfazer suas vontades, eles também se mostravam como agentes importantes para o cumprimento ou não dos planos previstos pela Coroa portuguesa.

\section{Conclusão}

Tendo como objetivo melhor compreender a atuação dos diretores de povoações ao tempo do Diretório dos Índios, destacamos duas questões relacionadas a esses sujeitos. A primeira delas diz respeito ao seu universo socioeconômico. Vimos que se muitos diretores, no interior das vilas e lugares, estavam próximos de produções extrativas, agrícolas e da mão de obra indígena, o que lhes permitia utilizá-las em benefício próprio, tantos outros,

\footnotetext{
${ }^{51}$ Ver: FARAGE, Nádia, op. cit., 1991; DOMINGUES, Ângela, op. cit., 2000, p. 249-295; COELHO, Mauro Cezar, op. cit., 2005; FONTENELE, Francisca Nescylene, op. cit., 2008; ROCHA, Rafael Ale. Os oficiais índios na Amazônia pombalina: sociedade, hierarquia e resistência (1751-1798). Dissertação de mestrado, História, Programa de Pós-Graduação em História, Universidade Federal Fluminense, 2009; SAMPAIO, Patrícia Melo. Espelhos partidos: etnia, legislação e desigualdade na Colônia. Manaus: Editora da Universidade Federal do Amazonas, 2011.

52 SAMPAIO, Patrícia Melo. Índios e brancos na Amazônia portuguesa: políticas e identidades no século XVIII. In: ALONSO, José Luis Ruiz-Peinado; CHAMBOULEYRON, Rafael (org.). In: Trópicos de História: gente, espaço e tempo na Amazônia (séculos XVII a XXI). Belém: Editora Açaí/Programa de Pós-Graduação em História Social da Amazônia (UFPA) / Centro de Memória da Amazônia (UFPA), 2010, p. 104.
} 
por outro lado, tinham que conviver com a escassez dessas fontes de riqueza, além de outras dificuldades, como a possibilidade sempre iminente das revoltas indígenas.

Apontar alguns desses empecilhos contribui para problematizar a visão unitária que foi construída sobre os diretores de povoações. Destacá-las, pode ajudar não apenas na melhor compreensão acerca do trabalho desses agentes, mas também no redimensionamento dos impactos ocasionados pelo exercício das diretorias. Talvez, um caminho interessante a se fazer implique em não criar generalizações sobre a atuação dos diretores. Isto porque algumas variáveis devem ser consideradas para a análise de suas ações, as quais poderiam estar relacionadas com outros fatores, como a riqueza ou a pobreza da povoação administrada. Por exemplo, cabe perscrutar a documentação a fim de averiguar se os descumprimentos à lei realizados pelos diretores eram diretamente ou inversamente proporcionais à produtividade de determinada povoação.

O trabalho buscou também problematizar a ideia dos diretores enquanto agentes decisivos para o fracasso do Diretório dos Índios. Baseandose nas dificuldades pelas quais muitos desses agentes passavam no interior das povoações, assim como no fato das transgressões se mostrarem como regra no Vale Amazônico ao tempo da segunda metade do século XVIII, consideramos mais proveitoso focarmos não no grau de participação de um ou de outro agente no desfecho da lei indigenista aqui analisada, mas, sim, nos motivos que os levavam a agir de tal maneira. Dessa forma, utilizava-se da transgressão, em muitos momentos, pois esta era entendida como uma prática indispensável à sobrevivência no Vale Amazônico. Por meio dela, obtinham-se importantes riquezas locais, como era o caso dos produtos extrativos, agrícolas e da mão de obra indígena.

\section{Referências bibliográficas}

\section{Fontes impressas}

DANIEL, padre João. Tesouro descoberto no máximo rio Amazonas. v. 1. Rio de Janeiro: Contraponto, 2004.

DIRECTORIO que se deve observar nas Povoaçoens dos Índios do Pará e Maranhão em quanto Sua Magestade não mandar o contrário. In: ALMEIDA, Rita Heloísa de. O Diretório dos Índios: um projeto de civilização no Brasil do século XVIII. Brasília: UnB, 1997.

LEI porque V. Magestade ha por bem restituir aos Índios do Grão Pará e Maranhão a liberdade de suas pessoas, bens e commercio. In: MOREIRA NETO, Carlos de Araújo. Índios na Amazônia, de maioria à minoria (1750-1850). Petrópolis: Vozes, 1988, p. 152-164. 


\section{Bibliografia}

ALDEN, Dauril. O significado da produção de cacau na região amazônica no fim do período colonial: um ensaio de história econômica comparada. Belém: UFPA/NAEA, 1974.

ALMEIDA, Maria Regina Celestino de. A falácia do povoamento: ocupação portuguesa na Amazônia setecentista. In: COELHO, Mauro Cezar; GOMES, Flavio dos Santos; QUEIROZ, Jonas Marçal de; MARIN, Rosa Elizabeth Azevedo; PRADO, Geraldo (org.). Meandros da História: trabalho e poder no Pará e Maranhão, séculos XVIII e XIX. Belém: UNAMAZ, 2005.

Os vassalos d'el rey nos confins da Amazônia: a colonização da Amazônia Ocidental. 1750-1798. Dissertação de mestrado, História, Instituto de Ciências Humanas e Filosofia, Universidade Federal Fluminense, 1990.

ALMEIDA, Rita Heloísa de. O Diretório dos Índios: um projeto de civilização no Brasil do século XVIII. Brasília: Universidade de Brasília, 1997.

AZEVEDO, João Lúcio de. Os jesuítas no Grão-Pará: suas missões e a colonização - bosquejo histórico com vários documentos inéditos. Belém: Secretaria de Estado e Cultura, 1999.

BEZERRA NETO, José Maia. Escravidão negra no Grão-Pará (séculos XVII-XIX). $2^{\mathrm{a}}$ ed. Belém: Paka-Tatu, 2012.

CAVALCANTE, Paulo. Negócios de trapaça: caminho e descaminhos na América portuguesa (1700-1750). Tese de doutorado, História, Programa de Pós-Graduação em História Social, Universidade de São Paulo, 2002.

COELHO, Mauro Cezar. Do sertão para o mar. Um estudo sobre a experiência portuguesa na América a partir da colônia: o caso do Diretório dos Índios (1751-1798). Tese de doutorado, História, Programa de Pós-Graduação em História Social, Universidade de São Paulo, 2005.

COSTA, Francisco de Assis. Lugar e significado da gestão pombalina na economia colonial do Grão-Pará. Nova Economia. Belo Horizonte, v. 20, fasc. 1, 2010, p. 167-206.

DIAS, Manuel Nunes. As frotas do cacau da Amazônia (1756-1777): subsídios para o estudo do fomento ultramarino português no século XVIII. Revista de História. São Paulo, fasc. 50, 1962, p. 363-377.

DOMINGUES, Ângela. Quando os índios eram vassalos. Colonização e relações de poder no Norte do Brasil na segunda metade do século XVIII. Lisboa: Comissão Nacional para as Comemorações dos Descobrimentos Portugueses, 2000.

FARAGE, Nádia. As muralhas dos sertões: os povos indígenas no rio Branco e a colonização. Rio de Janeiro: Paz e Terra; ANPOCS, 1991.

FONTENELE, Francisca Nescylene. Grão-Pará pombalina: trabalho, desigualdade e relações de poder. Dissertação de mestrado, História, Programa de Estudos Pós-Graduados, Pontifícia Universidade Católica de São Paulo, 2008.

HEMMING, John. Árvore de rios: A história da Amazônia. São Paulo: Senac-SP, 2011.

LOPES, Patricia Raiol Castro de Melo. Os corpos de trabalhadores na província do Grão-Pará: Outros significados para uma política de arregimentação da mão de obra (1835-1840). Dissertação de mestrado, História, Programa de Pós-Graduação em História Social da Amazônia, Universidade Federal do Pará, 2012. 
PIJNING, Ernst. Contrabando, ilegalidade e medidas políticas no Rio de Janeiro do século XVIII. Revista Brasileira de História. São Paulo, v. 21, fasc. 42, 2001, p. 397-414.

PRADO JÚNIOR, Caio. Formação do Brasil contemporâneo: colônia. $1^{\mathrm{a}}$ ed. São Paulo: Companhia das Letras, 2011.

REIS, Arthur Cezar Ferreira. A Amazônia e a cobiça internacional. Rio de Janeiro: Civilização Brasileira, 1982.

ROCHA, Rafael Ale. Os oficiais índios na Amazônia pombalina: sociedade, hierarquia e resistência (1751-1798). Dissertação de mestrado, História, Programa de Pós-Graduação em História, Universidade Federal Fluminense, 2009.

ROLLER, Heather Flynn. Expedições coloniais de coleta e a busca por oportunidades no sertão amazônico. 1750-1800. Revista de História. São Paulo, fasc. 168, 2013, p. 201-243.

SAMPAIO, Patrícia Melo. Espelhos partidos: etnia, legislação e desigualdade na Colônia. Manaus: Editora da Universidade Federal do Amazonas, 2011.

Índios e brancos na Amazônia portuguesa: políticas e identidades no século XVIII. In: ALONSO, José Luis Ruiz-Peinado; CHAMBOULEYRON, Rafael (org.). In: Trópicos de História: gente, espaço e tempo na Amazônia (séculos XVII a XXI). Belém: Editora Açaí/Programa de Pós-Graduação em História Social da Amazônia (UFPA) / Centro de Memória da Amazônia (UFPA), 2010.

SOUSA, Eveline Almeida de. Os ideais de civilização na Amazônia imperial (1845-1889). Dissertação de mestrado, História, Programa de Pós-Graduação em História Social da Amazônia, Universidade Federal do Pará, 2011.

SOUZA JÚNIOR, José Alves de. Tramas do cotidiano: religião, política, guerra e negócios no Grão-Pará do Setecentos. Um estudo sobre a Companhia de Jesus e a política pombalina. Tese de doutorado, História, Programa de Pós-Graduação em História Social, Pontifícia Universidade Católica de São Paulo, 2009. 